\title{
A Case Report of Abnormal Fracture Healing as Detected With High-Resolution Peripheral Quantitative Computed Tomography
}

Citation for published version (APA):

Heyer, F. L., de Jong, J. J. A., Smeets, R. J. E. M., Arts, J. J., Poeze, M., Geusens's, P. E., van Rietbergen, B., van den Bergh, J. P., \& Willems, P. C. (2017). A Case Report of Abnormal Fracture Healing as Detected With High-Resolution Peripheral Quantitative Computed Tomography. Journal of Clinical Densitometry, 20(4), 486-489. https://doi.org/10.1016/j.jocd.2017.05.004

Document status and date:

Published: 01/01/2017

DOI:

10.1016/j.jocd.2017.05.004

Document Version:

Publisher's PDF, also known as Version of record

Document license:

Taverne

Please check the document version of this publication:

- A submitted manuscript is the version of the article upon submission and before peer-review. There can be important differences between the submitted version and the official published version of record.

People interested in the research are advised to contact the author for the final version of the publication, or visit the DOI to the publisher's website.

- The final author version and the galley proof are versions of the publication after peer review.

- The final published version features the final layout of the paper including the volume, issue and page numbers.

Link to publication

\footnotetext{
General rights rights.

- You may freely distribute the URL identifying the publication in the public portal. please follow below link for the End User Agreement:

www.umlib.nl/taverne-license

Take down policy

If you believe that this document breaches copyright please contact us at:

repository@maastrichtuniversity.nl

providing details and we will investigate your claim.
}

Copyright and moral rights for the publications made accessible in the public portal are retained by the authors and/or other copyright owners and it is a condition of accessing publications that users recognise and abide by the legal requirements associated with these

- Users may download and print one copy of any publication from the public portal for the purpose of private study or research.

- You may not further distribute the material or use it for any profit-making activity or commercial gain

If the publication is distributed under the terms of Article $25 \mathrm{fa}$ of the Dutch Copyright Act, indicated by the "Taverne" license above, 


\title{
A Case Report of Abnormal Fracture Healing as Detected With High-Resolution Peripheral Quantitative Computed Tomography
}

\author{
Frans L. Heyer, ${ }^{*, 1,2,3}$ Joost J.A. de Jong, ${ }^{1,4}$ Rob J.E.M. Smeets, ${ }^{5,6}$ Jacobus J. Arts, ${ }^{5,7}$ \\ Martijn Poeze, ${ }^{1,2}$ Piet P. Geusens, ${ }^{4,5,8}$ Bert van Rietbergen, ${ }^{9}$ \\ Joop P. van den Bergh, ${ }^{1,3,4,8}$ and Paul C. Willems,
}

\begin{abstract}
${ }^{1}$ Research School NUTRIM, Maastricht University, The Netherlands; ${ }^{2}$ Department of Surgery, Maastricht University Medical Center, The Netherlands; ${ }^{3}$ Department of Internal Medicine, VieCuri Medical Center Venlo, The Netherlands; ${ }^{4}$ Department of Rheumatology, Maastricht University Medical Center, The Netherlands; ${ }^{5}$ Research School CAPHRI, Maastricht University, The Netherlands; ${ }^{6}$ Department of Rehabilitation Medicine, Libra Rehabilitation and Audiology location Eindhoven/Weert, The Netherlands; ${ }^{7}$ Department of Orthopedic Surgery, Maastricht University Medical Center, The Netherlands; ${ }^{8}$ Faculty of Medicine and Life Sciences, Hasselt University, Belgium; and ${ }^{9}$ Faculty of Biomedical Engineering, Eindhoven University of Technology, The Netherlands
\end{abstract}

Key Words: Bone; case report; fracture healing; HR-pQCT.

\section{Introduction}

Fracture healing is a complex repair process with the primary objective of restoring the mechanical function of the fractured bone (1). Quantifying outcome in clinical fracture healing trials remains challenging $(2,3)$. Using highresolution peripheral quantitative computed tomography (HR-pQCT) in combination with micro finite element analysis $(\mu \mathrm{FEA})$, we previously described the typical healing of a distal radius fracture. This process consists of an increase in bone density of the trabecular compartment peaking at $6 \mathrm{wk}$ post fracture, corresponding to the formation of a mineralized fracture callus $(4,5)$. In the present case report, we describe a patient who deviated from this usually observed pattern of fracture healing.

Received 05/4/17; Accepted 05/8/17.

Disclosures: J.J. Arts is a board member of the workgroup Biotechnology of the Dutch Orthopedic Association (NOV) and a board member of the Dutch Society of Biomaterials and Tissue Engineering (NBTE). B. van Rietbergen is a consultant for Scanco Medical AG. P.C. Willems is a board member of the Dutch Spine Society (association of spine surgeons). F.L. Heyer, J.J.A. de Jong, R.J.E.M. Smeets, M. Poeze, P.P. Geusens, and J.P. van den Bergh declare that they have no conflict of interest.

*Address correspondence to: Frans L. Heyer, MD, Department of General Surgery, Maastricht University Medical Center, P.O. Box 5800, 6202 AZ Maastricht, The Netherlands. E-mail: f.heyer@maastrichtuniversity.nl

\section{Patient and Methods}

\section{Case Report}

A 54-yr-old woman visited our emergency department with a displaced distal radius fracture of the left arm after a fall from standing height. After a successful closed reduction at the emergency room, the patient was treated by cast immobilization. Six weeks post fracture, the patient complained of increased pain, swelling, and stiff fingers. Physical examination revealed no neurological or vascular impairment. Standard radiographs showed incomplete consolidation of the fracture without secondary dislocation. Cast immobilization was continued for 2 more weeks. At the 8-wk outpatient clinic visit, a decreased motor function of the extensor muscles of the left wrist and all digits without sensory disturbances was observed. Radiographic examination showed delayed but progressing consolidation (Supplemental Fig. S1). Physical therapy was started. Three months after the fracture, the left lower arm was swollen and showed a purple discoloration. Active flexion and extension of the left wrist and digits were $0^{\circ}$ in all axes, and active and passive movements of the left shoulder were limited. Electromyography of the left arm revealed conduction abnormalities of the radial nerve near the wrist, and ulnar and median nerve injuries at elbow level. Three months post fracture, the patient met the Budapest clinical and research criteria (6) for complex regional pain syndrome (CRPS) type 1 . Subsequent multidisciplinary treatment consisted of graded exposure therapy, transcutaneous electrical nerve stimulation, amitriptyline, 
dimethyl sulfoxide $50 \%$, pregabalin, calcitonin, paracetamol, and tramadol. At the last follow-up, 3 yr post fracture, active motion of the left wrist was $0^{\circ}$ in all axes and both spontaneous pain and allodynia were present, although the patient was able to use her affected hand to a greater extent during normal daily activities than before treatment.

Routine screening on osteoporosis with dual-energy $\mathrm{X}$-ray absorptiometry and laboratory examination showed osteopenia at the lumbar spine and proximal femur, and secondary hyperparathyroidism (parathyroid hormone $8.0 \mathrm{pmol} / \mathrm{L}$, ref. 1.3-6.8), due to vitamin D deficiency $(25(\mathrm{OH})$ vitamin D: $33 \mathrm{nmol} / \mathrm{L}$, ref. $>75 \mathrm{nmol} / \mathrm{L})$. With cholecalciferol supplementation, the latter was resolved by 12 wk post fracture $(25(\mathrm{OH})$ vitamin $\mathrm{D}: 67 \mathrm{nmol} / \mathrm{L}$, parathyroid hormone $4.5 \mathrm{pmol} / \mathrm{L})$.

\section{HR-pQCT Measurements}

HR-pQCT is a low-dose radiographic imaging modality with an isotropic voxel size of 82 (XtremeCT-1; Scanco

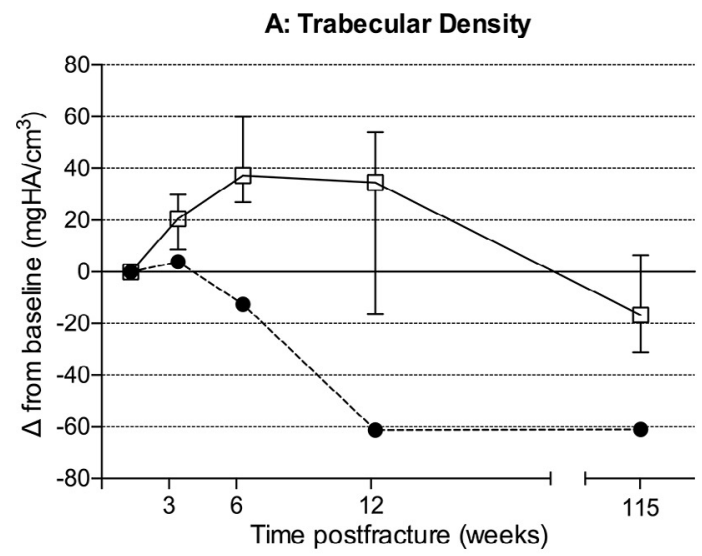

C: Cortical Density

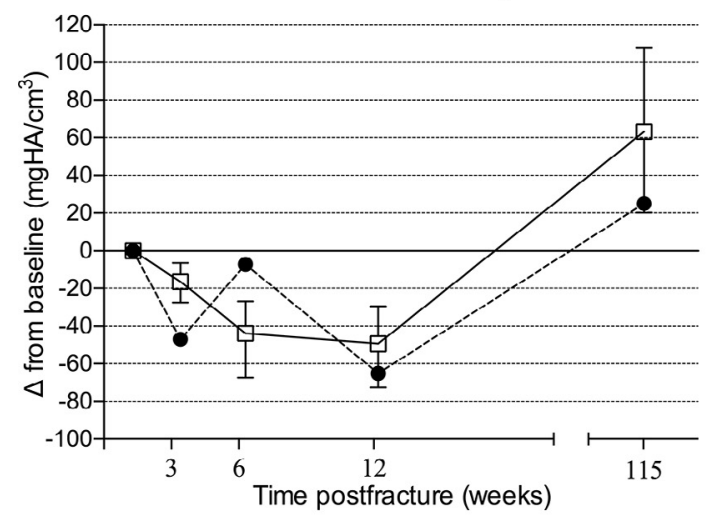

$\square$ Group
Medical AG, Brüttisellen, Switzerland). The high resolution enables the assessment of bone microarchitecture in vivo (7) and estimation of bone strength $\mu$ FEA (8).

HR-pQCT scans (XtremeCT-1) were performed at 1,3, 6,12 , and $115 \mathrm{wk}$ post fracture using the manufacturer's clinical in vivo settings (effective energy of $60 \mathrm{kVp}$, tube current of $900 \mu \mathrm{A}$, and $100-\mathrm{ms}$ integration time), in accordance with the approved study protocol (NTR3821). From these images, bone density, geometry, and microarchitectural and $\mu$ FEA parameters were derived $(4,5)$.

\section{Results}

Incongruent with the healing pattern observed with HRpQCT described earlier $(4,5)$, a decrease in trabecular density was detected at $6 \mathrm{wk}$ post fracture $(-11.9 \mathrm{mgHA} /$ $\mathrm{cm}^{3}$ ), where the typical healing response showed an increase (median $\left.+35.4 \mathrm{mgHA} / \mathrm{cm}^{3}\right)$. This deviation was not restored even after 115 wk (Fig. 1A). Simultaneously, the

B: Trabecular Number

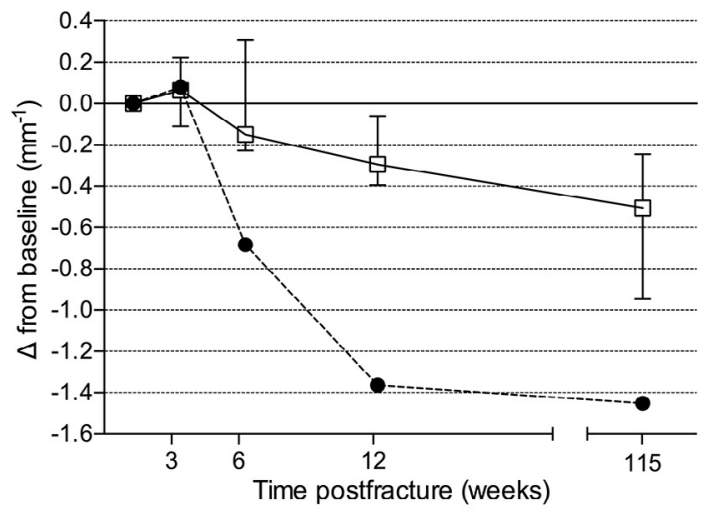

D: Compression Stiffness

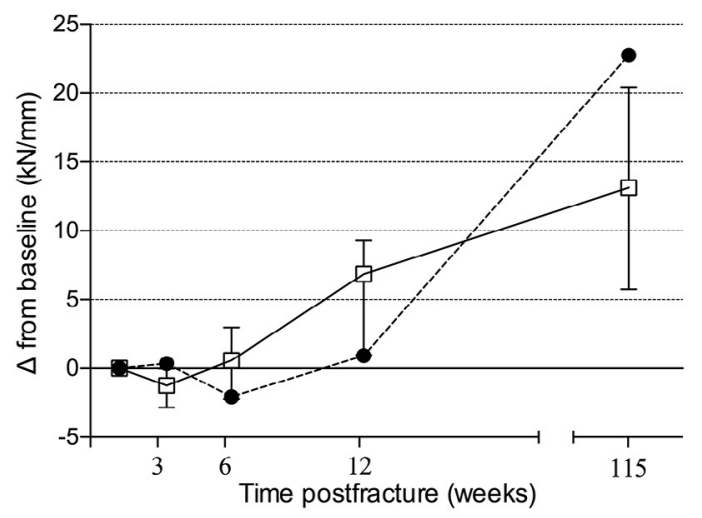

-- Case

Fig. 1. High-resolution peripheral quantitative computed tomography-derived bone parameters of the presented case of abnormal fracture healing (black circles) compared to the other subjects of the study cohort (white squares, $\mathrm{N}=14$ ). In the case patient, the trabecular density is seen to decrease early in the healing process, persisting up to 115 wk (A), along with the trabecular number $(\mathbf{B})$. In contrast to trabecular density, cortical density during fracture healing follows a normal pattern $(\mathbf{C})$, which explains the restored compression stiffness $(\mathbf{D})$. Data are presented as median with interquartile range. Scans were performed (on average) at 1,3,6,12, and 115 wk post fracture. 


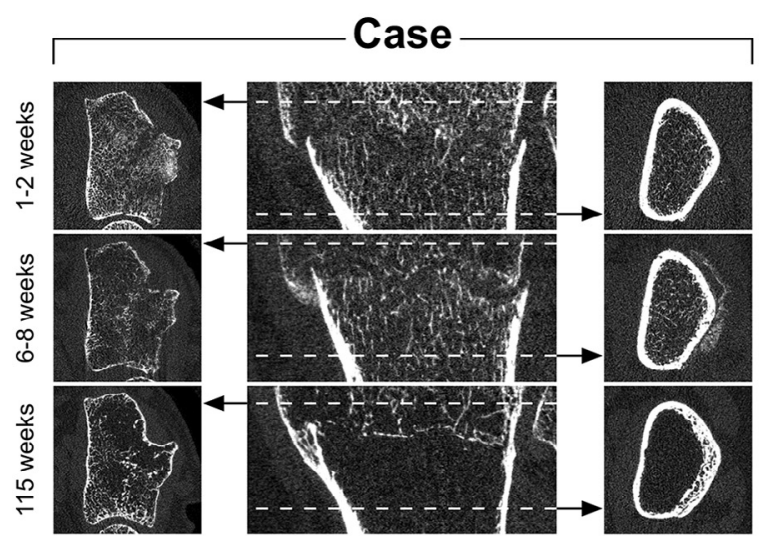

Segmented 3D reconstructions

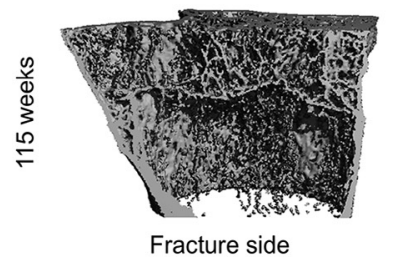

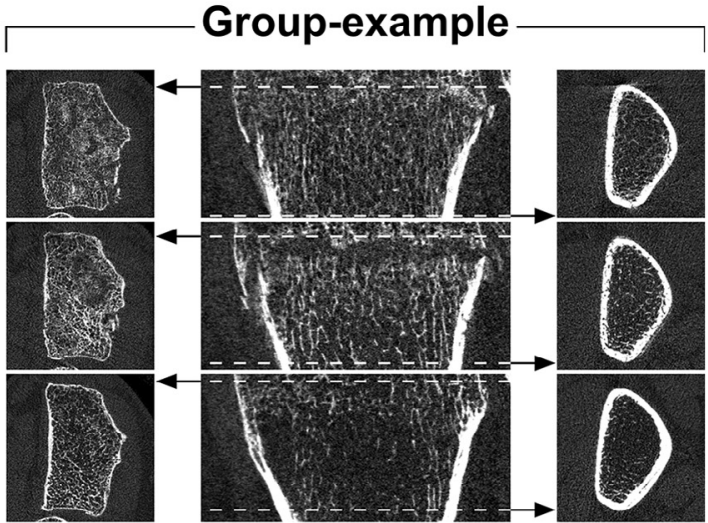

Segmented 3D reconstructions

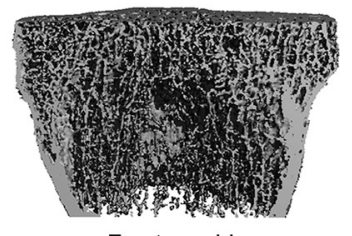

Fracture side

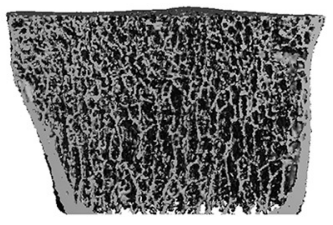

Contralateral side

Fig. 2. Representative slices from the presented case showing abnormal fracture healing, as compared to a patient representative of the observed healing pattern in the study group. After $115 \mathrm{wk}$, the trabecular structure is resorbed to a greater extent in the affected patient. The contrast between the region proximal and distal from the fracture line can be observed in particular in the segmented 3D reconstructions. 3D, 3-dimensional.

trabecular number declined significantly more from $6 \mathrm{wk}$ post fracture onward $\left(-0.7\right.$ vs median $\left.-0.2 \mathrm{~mm}^{-1}\right)$, a difference persisting up to $115 \mathrm{wk}\left(-1.5 \mathrm{vs}\right.$ median $-0.5 \mathrm{~mm}^{-1}$, Fig. 1B).

In contrast, the cortical region healed normally, following a similar pattern as the other patients in the study (Fig. 1C). As a result, calculated compression stiffness using $\mu$ FEA was comparable to the other patients (Fig. 1D).

Visual inspection of the HR-pQCT reconstructions confirmed cortical healing. The axial and coronal reconstructions show that the trabecular bone loss in the deviating patient (case) was more extensive than the generally observed decline in trabecular density and structure (Fig. 2 and Supplemental Video S1). This is especially evident in the segmented 3-dimensional reconstructions. Remarkably, these images also indicate that the trabecular bone loss occurred predominantly in the region proximal to the fracture line (Fig. 2).

\section{Discussion}

The present case report demonstrates the potential of HR-pQCT to distinguish different patterns of fracture healing in a clinical setting. In a single patient, we detected a remarkable resorption of trabecular bone proximal to the fracture line, whereas the cortical bone healed normally. These regional discrepancies were not detected to this extent in the other patients with a fracture of the distal radius.
The relevance of CRPS in the present case report is uncertain. Although regional osteoporosis was part of the CRPS spectrum when it was first described by Paul Sudeck in 1900 (9), current clinical imaging techniques are unable to discriminate normal posttraumatic bone loss as a result of immobilization and disuse from bone loss concurring with CRPS development (10). However, the data presented here are in accordance with the recent suggestion that HRpQCT could be a solution to this challenge (11): the trabecular bone loss discriminated the patient with CRPS from the other study participants (4) as early as 6 wk post fracture, a period characterized by cast immobilization for all subjects. Nonetheless, CRPS remains an elusive clinical syndrome subject to much debate (12-14). Using HR-pQCT, the incidence and role of localized bone loss within the CRPS population could be further elucidated.

A limitation of the present case report is that it only presents a single affected patient to illustrate the detection of abnormal fracture healing using HR-pQCT. Additionally, based on the current data available to us, the etiology of the observed bone loss is not certain and can only be speculated on. However, this case report indicates that HRpQCT offers a new way of looking at abnormal fracture healing even before the presentation of clinical symptoms.

\section{Acknowledgments}

The authors would like to thank Liesbeth Jutten and Margareth Winants from the Trial Bureau of the Department 
of Orthopedics for their efforts during this study. This study was funded by the Weijerhorst Foundation (grant no. WH2).

\section{Appendix Supplementary material}

Supplementary data to this article can be found online at doi:10.1016/j.jocd.2017.05.004.

\section{References}

1. Einhorn TA. 1998 The cell and molecular biology of fracture healing. Clin Orthop Relat Res 355(Suppl):S7-S21.

2. Bottlang M, Augat P. 2014 The bottleneck of evidencebased fracture care. Injury 45(Suppl 2):S1-S2.

3. Einhorn TA. 2014 Invited commentary. J Orthop Trauma 28(1):62.

4. de Jong JJA, Willems PC, Arts JJ, et al. 2014 Assessment of the healing process in distal radius fractures by high resolution peripheral quantitative computed tomography. Bone 64:65-74.

5. de Jong JJ, Heyer FL, Arts JJ, et al. 2016 Fracture repair in the distal radius in postmenopausal women: a follow-up 2 years postfracture using HRpQCT. J Bone Miner Res 31(5):1114-1122.
6. Harden RN, Oaklander AL, Burton AW, et al. 2013 Complex regional pain syndrome: practical diagnostic and treatment guidelines, 4th edition. Pain Med 14:180-229.

7. Boutroy S, Bouxsein ML, Munoz F, Delmas PD. 2005 In vivo assessment of trabecular bone microarchitecture by highresolution peripheral quantitative computed tomography. J Clin Endocrinol Metab 90(12):6508-6515.

8. MacNeil JA, Boyd SK. 2008 Bone strength at the distal radius can be estimated from high-resolution peripheral quantitative computed tomography and the finite element method. Bone 42(6):1203-1213.

9. Sudeck P. 2005 On acute inflammatory bone atrophy. J Hand Surg [Br] 30(5):477-481.

10. Schürmann M, Zaspel J, Löhr P, et al. 2007 Imaging in early posttraumatic complex regional pain syndrome: a comparison of diagnostic methods. Clin J Pain 23(5):449-457.

11. Lascombes P, Mamie C. 2016 Complex regional pain syndrome type I in children: what is new? Orthop Traumatol Surg Res 103(1):S135-S142.

12. Borchers AT, Gershwin ME. 2014 Complex regional pain syndrome: a comprehensive and critical review. Autoimmun Rev 13(3):242-265.

13. Borchers AT, Gershwin ME. 2017 The clinical relevance of complex regional pain syndrome type I: the emperor's new clothes. Autoimmun Rev 16(1):22-33.

14. Frölke JPM, van Dongen RT, van de Meent H. 2015 Complex regional pain syndrome type 1: negating the myth. Ned Tijdschr Geneeskd 159:A8370. 